ACTA THERIOLOGICA

Vol. 22, 33: 485-508, 1977

\title{
The Occurrence and Some Ecological Parameters of the Moose in Poland
}

\author{
Andrzej TOMEK
}

\begin{abstract}
Tomek A., 1977: The occurrence and some ecological parameters of the moose in Poland. Acta theriol., 22, 33: 485-508 [With 12 Tables \& 3 Figs.].

It has been established, on the basis of a study carried out in 8 chosen forest districts in 1968-1971 and the questionnaires filled up by the forest administration offices throughout the country, that in 1971 the mooses Alces alces ( $\mathrm{L}$ in na e us, 1758) lived in 18 regions in Poland including 88 forest districts. The number of mooses and that of the forest districts inhabited by this species had been increasing up to 1971 . The moose colonized the lowland forest complexes varying in size but always showing a sufficiently large area of bogs with abundant understorey of shrubs and trees. The real growth of moose populations averaged $42-64 \%$ of the number of cows, and the ratio of bulls to cows ranged between 0.79 and 0.99 . The mean density of mooses was from 2.1 to 8.0 individuals per 1000 ha of the forest area. Moreover, it has been found that there is a tendency towards density autoregulation of mooses in crowded regions, by migration and decrease in population growth. A migration of 154 individuals around 315 forest districts all over the country was observed in 1971. In 1968-1971 338 mooses were shot in Poland, only about $40 \%$ of the real population growth being thus taken. Beside that the greatest losses in the population were caused by poaching, diseases and drownings. No major influence of human interference on the development and life of the moose population was observed. The moose to have found favourable living conditions in Poland.

[Inst. Forest Protect., Agric. Academy, al. 29-go Listopada 48, 31-425 Kraków]
\end{abstract}

\section{INTRODUCTION}

In the past the moose Alces alces ( $\mathrm{L}$ innae us, 1758) inhabited most of the wooded areas in Poland (Gustawicz, 1901), but after its extermination it was a rare member of the Polish fauna for many years. After 1945 there remained several mooses $(4-6)$ in the Czerwone Bagno Reserve in the basin of the River Biebrza in north-eastern Poland. Since the extinction of mooses in Poland was imminent, four individuals were imported from Sweden to Białowieża in 1948 and five from the Nowogródek region (Byelorussian SSR) to Kampinos near Warsaw in 1951. The mooses failed to stay in the reserve in the Białowieża Forest, while in the Kampinos Forest they had multiplied so much that 14 out of the 25 animals living there were set free in 
1956 and the rest of them in 1959 (K a r pinski, 1952; Kaempf, 1966; P ielowski, 1969).

At the beginning of the sixtieth single individuals emigrated from Kampinos and Czerwone Bagno, reaching as far as the GDR and Czechoslovakia. At the same time mooses immigrating from the Soviet Union began to appear in Poland (Heyden reich, 1958, 1961; Hi a ber, 1962; Chudik \& Sládek, 1962). Individuals migrating from home and foreign localities spread all over Poland, increasing constantly in number ( $\mathrm{N}$ o w a k, 1971).

In 1959 the moose entered on the list of game, but it was still preserved all the year round till 1966, although there was no danger of its extinction in Poland any longer ( $\mathrm{Stadion-Rzyszczew-}$ $\mathrm{ski}$ 1960; Tomek 1969). Shooting of predetermined numbers of mooses in crowded regions was started in 1966, when the damage done by them in forestry became heavy (F a f in ski, 1969; Szczepkowski, 1969; P a sław ski, 1971).

On account of its scanty occurrence the moose was given no extensive study for many tens of years and this is why in 1968 an investigation was taken up, the purpose of which was (1) to determine the areas inhabited by mooses in Poland and to examine the changes in their range, (2) to establish the dynamics of the size and structure of the moose population, which is important to the planning of rational game management and (3) to get to know the ecological requirements of the moose, which would facilitate the forecast of the development of its population under conditions of cultivated forests.

\section{METHODS AND MATERIAL}

Collection of material was started in 1968 by sending questionnaire forms to all the forest administration offices and managements of national parks in Poland, in order to estimate the numbers of residing and migrating mooses. The possibilities of errors, pointed out by Bogucki (1957), were taken into account and the questionaire was simplified so as to leave no room for doubt as to the answers to two questions, i.e. whether mooses occurred permanently in the given forest district (how many and since when they had lived there) and, if their habitation had not been ascertained, whether migrating specimens had been seen (date and sex, if distinguished).

The same questinaires were sent in 1971 and a comparison of answers provided information about the development of the moose populations.

In both cases the course of inquiry was similar. About $80 \%$ of the answers reached within two months and the rest after reminders had been sent. In both inquiries about $99 \%$ of the questionnaires were answered.

After all the data had been collected, they were verified by random checking the information on the spot and comparing it with the answers concerning the neighbouring regions. Most answers were found to be consistent with reality, 
for we managed to note the time and direction of migrating specimens, which in turn permitted conclusions as to their numbers. In some forest districts no mooses were observed, even though they visited these districts probably for a short time when on migration. The data concerning the numbers of mooses used in this paper were obtained from censuses carried out by the method of finding out the tracts of animals in the snow towards the end of winter in each year. This method may however be charged with errors, as has been demonstrated for the red-deer and roe-deer (Bobek \& $\mathrm{Tomek}, 1973$ ) and also for the moose (Sapetin \& Priklonskij, 1964).

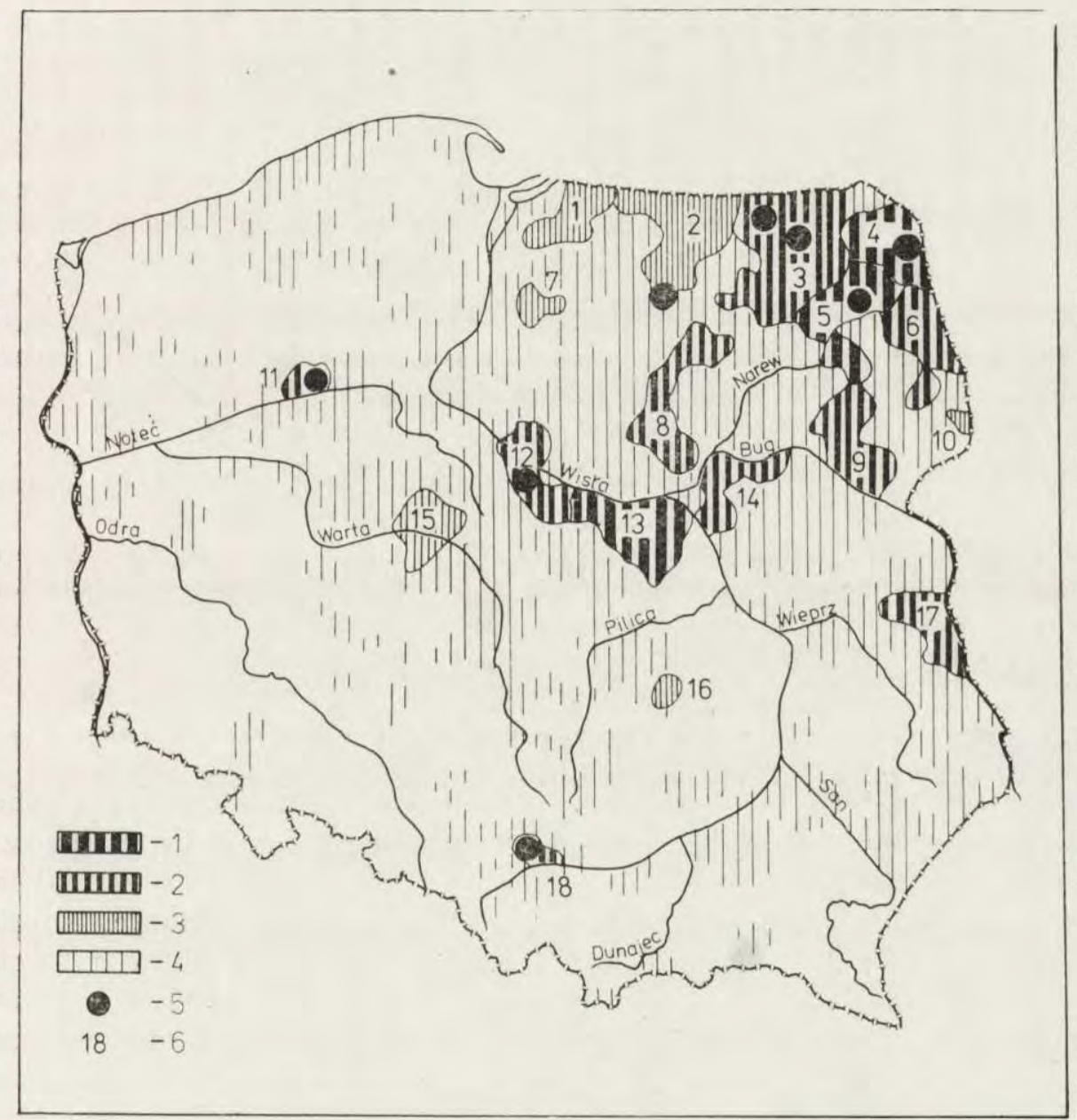

Fig. 1. Regions of habitation and migrations of mooses in Poland.

1 - Regions colonized before 1962, 2-Regions colonized in 1962-1963, 3-Regions colonized in 1968-1971, 4-Regions in which migrating mooses were recorded, 5 -Areas investigated closely, 6-Moose habitation region numbers (explanation in text). 
The forest districts in which at the time of inquiry bulls and cows had lived for two years and had brought forth their young were regarded as the habitation areas of mooses. In 1971 letters were sent to 62 forest administration offices in charge of districts in which moose habitation areas had been noted up to 1968 to request information about the natural conditions prevailing in them, i.e. the forest habitat types, plant species which make up the forest, the occurrence of running waters and bogs, osier-beds and plant species in the forest undergrowth, and also about the moose population size, allowable take of game and natural losses. The questions were formulated in such a way as to spare the answerers trouble and that the documents drawn up by them in the course of their routine work might be used in answering. The data concerning the natural conditions in the forest and allowable take of mooses rouse no doubt. The questions about the occurrence of undergrowth, osier-beds and disturbances in the habitation area, needing only yes or no answers, were also easy enough, and the data provided in them may also be regarded as reliable.

A close field study was carried out in the original habitation area of the moose at Czerwone Bagno and in seven forest districts colonized after 1945 (Fig. 1). Apart from the verification of the answers to all the questions contained in the questionnaire, during this field study the herds of moose were tracked and observed, the forest complexes colonized by mooses were described and their sections inhabited by mooses investigated closely, the stands of trees, undergrowth, food supply and water conditions being described.

Field observations were also made in 3 forest districts, which had been only visited by migrating mooses. The natural and physiographic conditions prevailing there were compared with those found in the areas inhabited by mooses, which threw some light on the ecological requirements of these animals.

During these field studies some workers of the state forest managements were intervied. Some of their observations, e.g. those on the habitation areas and the behaviour of mooses in relation to man, had a certain value and were utilized in this paper.

\section{DISTRIBUTION OF MOOSE IN POLAND}

A total of 1307 mooses were inventoried in Poland in 1971. The localities of their permanent habitation could be grouped in 18 distinct regions colonized in different years (Table 1, Fig. 1). The differentiation of physiographic and natural forest conditions or the distances which prevented animals from particular regions to keep in constant touch with each other were taken into account in distinguishing these regions. Nevertheless, there were migrations between some of the regions, especially those neighbouring on each other. The largest numbers of mooses lived in north-eastern and central Poland; there were also areas inhabited by them in other parts of the country, the River Notec region (11) being situated farthest to the west and the Dulowa region (18) farthest to the south. Poland was colonized by mooses coming from three sources: from the home habitation grounds in the Biebrza Basin (region 5), from the artificially set up locality in the Kampinos region (13) 


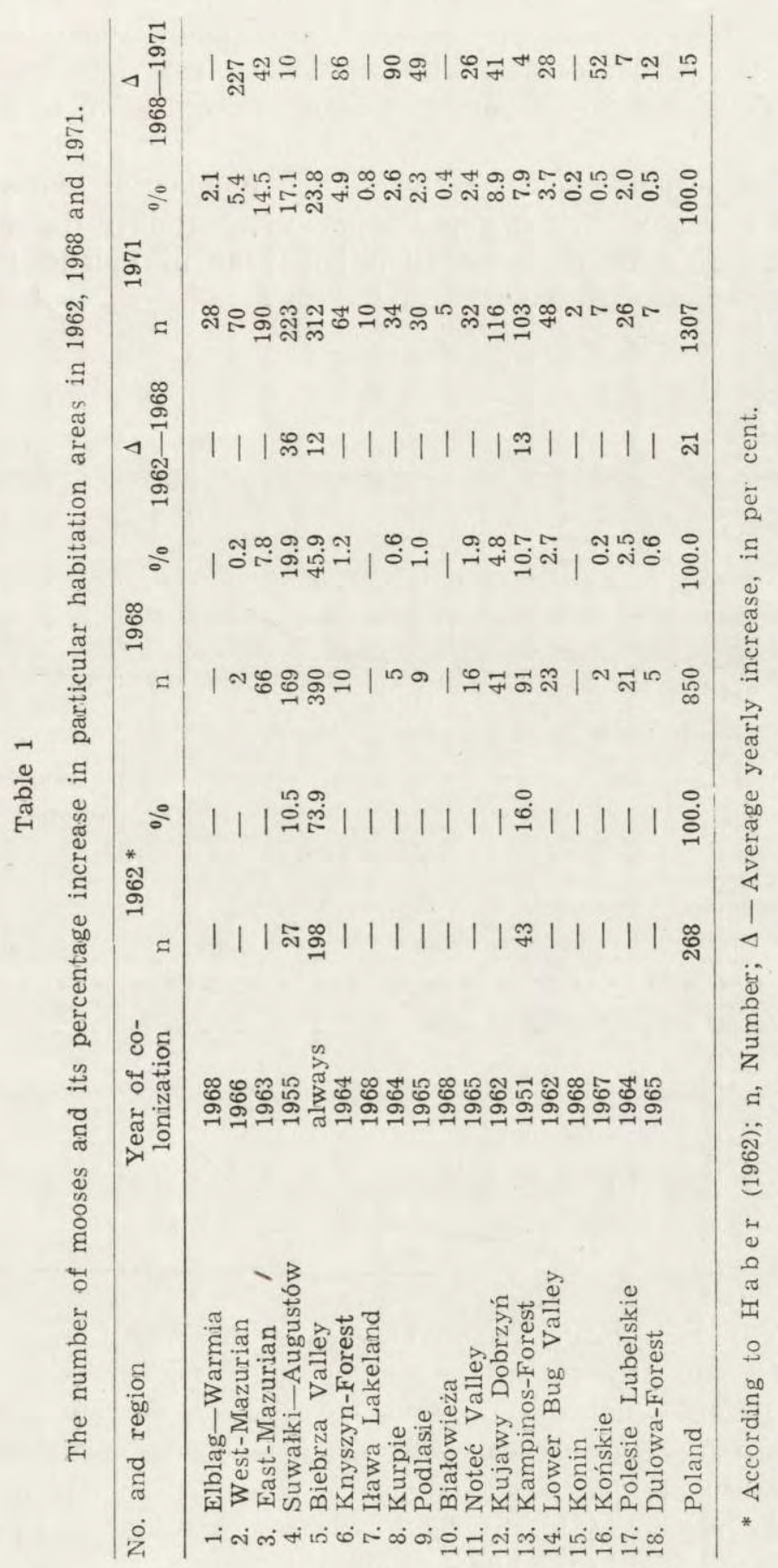


and from the Soviet Union (to regions 1, 2, 3, 4, 10 and 17). It seems, however, that most mooses west of the Vistula come from region 13 and in the border areas in the north and east from the USSR, e.g. region 17 is probably a part of a large concentration of mooses in the USSR.

In most regions (except region 5) the number of mooses was found to have increased, this increase being different in different region and averaging $15 \%$ of the population per year in Poland in 1968-1971

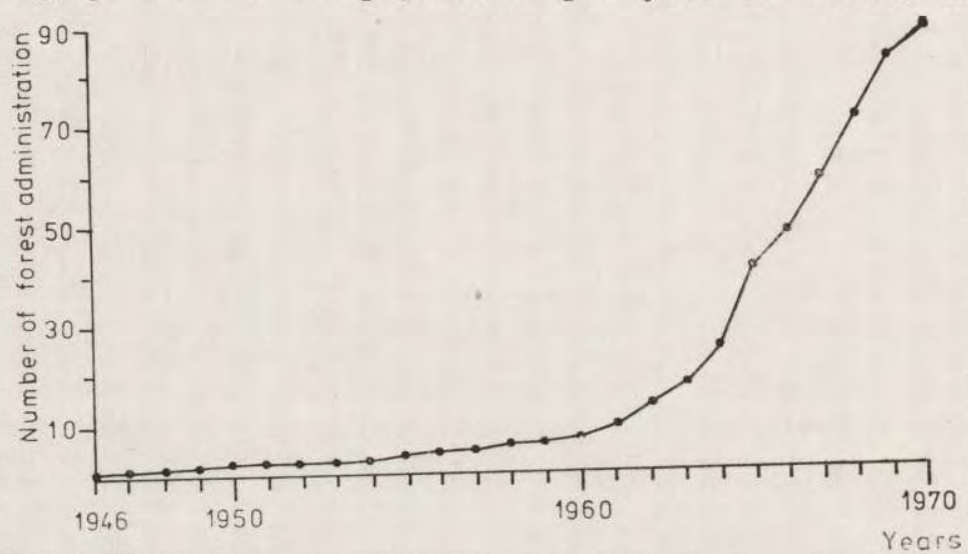

Fig. 2. Increase in the number of forest districts colonized by mooses in 1946-1970.

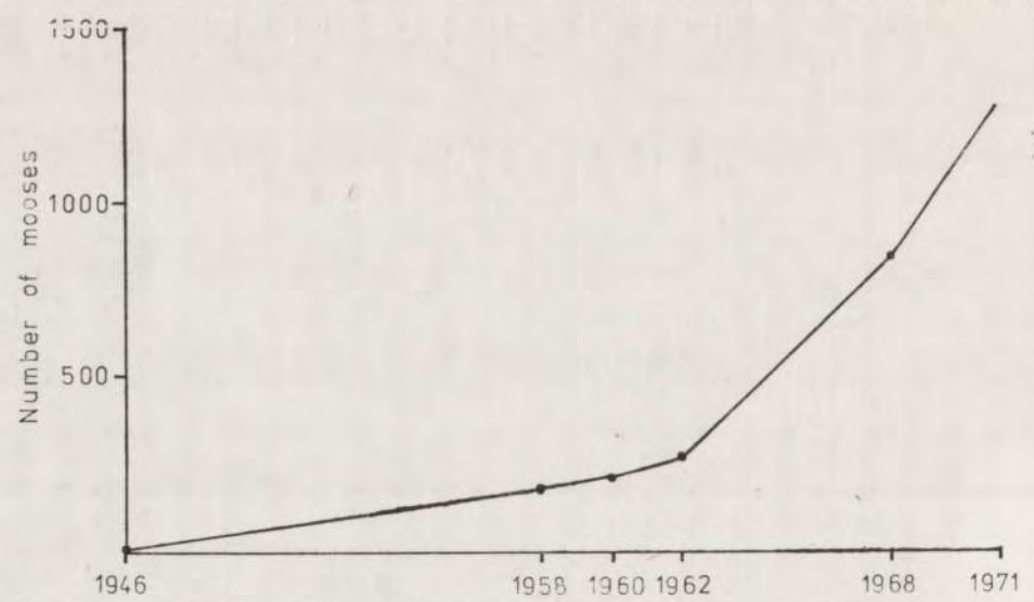

Fig. 3. Increase in the number of mooses living in Poland in 1946-1971.

(Table 1). The increase in the number of forest districts inhabited by mooses (Fig. 2) indicates that the colonization of new areas, observed in Poland since the sixties, went on till the end of this study period. The number of mooses and the areas occupied by them increased in particular regions (Fig. 3). The greatest increase in the number of mooses was found in the new-colonized regions. 


\section{MIGRATIONS OF MOOSES IN POLAND AND THEIR MOVEMENTS WITHIN HABITATION AREAS}

\subsection{Migrations Outside Habitation Areas}

The inquiry shows that migrating mooses were recorded in 315 forest districts ( $32 \%$ of their number in Poland) in 1968-1971 (Fig. 1). A comparison of the time of observations of migrating mooses in particular districts and the observed directions of migration made it possible to establish that about 150 specimens migrated in 1971.

The relatively intensest migration took place of northern, eastern and central Poland. The largest numbers of migrating mooses were observed in the vicinity of their habitation areas, but some of them migrated to places several hundred kilometers away (Fig. 1). Migrations of mooses were observed in all the seasons of the year, but the migrations of bulls were most often recorded in the autumn, those of cows in the spring and of cows with calves in the summer. The mooses most frequently wandered along riverside groves and forest edges, although cases of the appearance of single specimens in open areas, cultivated fields and occasionally in mountains are also known. As a result of such independent migrations of bulls and cows, the newly arising groups of mooses may sometimes have been composed of specimens coming from different regions.

Emigrations of mooses were observed in most regions, but the largest numbers of animals left the densely populated areas $(4,5,12$, 13 - Fig. 1), which indicated that one of the causes of migration may be the tendency towards the autoregulation of population density.

Many specimens perished of various causes during migration. Twentyfour cases of death of mooses migrating in Poland were recorded.

\subsection{Movements within Habitation Regions}

Apart from the migrations of mooses to other habitation regions, individual specimens or their groups moved within their own definite habitation area. This problem has been analyzed on the basis of the statements obtained for 62 forest districts inhabited by mooses. Seasonal migrations occurred in 23 forest districts; in 10 of them the mooses changed their summer habitation in alder woods and marshes for the winter one in young pine-woods, whereas in 13 districts the cause of movements has not been established. Irregular movements in different seasons most often aimed at the penetration of the extensive habitation area in search of feeding grounds. Migrations of bulls in the mating season were also observed in all the forest districts. 


\section{ECOLOGICAL REQUIREMENTS OF THE MOOSE IN POLAND}

\subsection{Living Conditions of the Moose in the Habitation Areas Examined}

The living conditions of the moose in eight forest districts examined closely differed in some ecological factors (Table 2). Here the mooses found areas characterized by various climatic conditions, the mean annual temperatures ranging between 5.6 and $7.6^{\circ} \mathrm{C}$ and the annual rainfall of 575-692 $\mathrm{mm}$. Hydromorphic, podsol and brown soils prevailed in the forest complexes colonized by the moose and at the same time more than $50 \%$ of their area was covered by alder woods or other deciduous or coniferous habitats. Out of the big herbivores, roe-deer and, not very numerous, red-deer occurred in all the forest districts examined, and at Borki (3) also European bisons (Bison bonasus L i n n a e s, 1758).

Special attention should be given to the original habitation of the

Table 2

General factors of the moose habitat in 8 closely examined forest districts.

\begin{tabular}{|c|c|c|c|c|c|c|c|c|}
\hline Region No.* & 2 & 3 & 3 & 4 & 5 & 11 & 12 & 18 \\
\hline 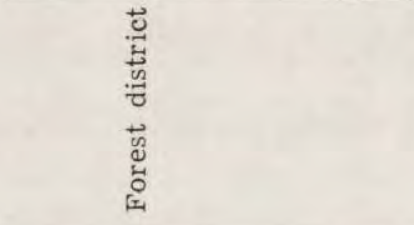 & $\begin{array}{l}0 \\
\vdots \\
0 \\
\infty \\
0 \\
3 \\
3\end{array}$ & 站 & $\begin{array}{l}0 \\
3 \\
0 \\
0 \\
0 \\
0 \\
0 \\
0 \\
3 \\
3\end{array}$ & 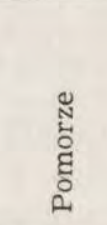 & 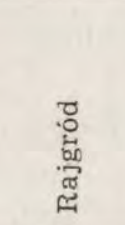 & $\frac{\pi}{\frac{\pi}{b}}$ & 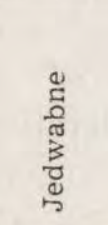 & 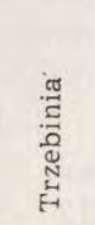 \\
\hline $\begin{array}{l}\text { Number of mooses } \\
\text { inhabiting in } 1971 \\
\text { Area of inhabited }\end{array}$ & 10 & 11 & 20 & 34 & 144 & 7 & 30 & 7 \\
\hline $\begin{array}{l}\text { forest complexes, ha } \\
\text { Occurrence of disturbance } \\
\text { caused by: }\end{array}$ & $\begin{array}{l}1500 \\
\text { es }\end{array}$ & 5500 & 1300 & 6700 & 12000 & 3000 & 7500 & 2300 \\
\hline Tourists & + & + & - & + & - & - & + & + \\
\hline Transport lines & + & - & - & - & - & + & + & + \\
\hline Nearby towns & + & - & - & - & - & - & + & + \\
\hline $\begin{array}{l}\text { Forest exploitation } \\
\text { Climatic conditions **: } \\
\text { Mean annual temperature }\end{array}$ & + & + & - & + & - & + & + & + \\
\hline $\begin{array}{l}\text { Mean annual temperature, } \\
\text { in }{ }^{\circ} \mathrm{C}\end{array}$ & 5.6 & 5.9 & 6.0 & 5.9 & 6.8 & 7.2 & 7.6 & \\
\hline $\begin{array}{l}\text { Annual rainfall, in } \mathrm{mm} \\
\text { Soils, in } \% \text { : }\end{array}$ & 585 & 627 & 587 & 658 & 583 & 575 & $?$ & 692 \\
\hline Hydromorphic & $?$ & 14 & 19 & 11 & 57 & 1 & 1 & 10 \\
\hline Podsol & ? & 6 & 2 & 89 & 35 & 99 & 99 & 90 \\
\hline $\begin{array}{l}\text { Brown } \\
\text { Habitat, in } \% \text { : }\end{array}$ & ? & 80 & 55 & - & 8 & - & - & - \\
\hline Alder woods & 5 & 13 & 15 & 2 & 41 & 0.5 & 1.3 & 2 \\
\hline Deciduous forests & 70 & 75 & 53 & 1 & 9 & 0.6 & 0.5 & 4 \\
\hline Coniferous forest & 25 & 12 & 32 & 97 & 50 & 98.9 & 98.2 & 94 \\
\hline
\end{tabular}

* Region numbers same as in Table 1 and Fig. 1; ** Data from the meteorological stations situated in the forest districts. 
moose in the Rajgród forest district (region 5-Fig. 1), for it is only there that the moose has survived since the oldest times and it may be supposed that there it has found the most favourable conditions (Table 2). The complexes of this forest district and adjacent regions (Grajewo and Trzcianne forest districts) form together a large area of more than 10000 hectares of forests and extensive marshes in the valley of the rivers Biebrza and Ełk and the Augustów Canal, crossed by numerous smaller streams. The mooses are preserved in the Czerwone Bagno Reserve, 1480 ha in area, overgrown by vegetation characteristic of the biotope types of the proper alder wood (Carici elongate-Alnetum) in the marshy coniferous forest (Vaccinio uliginosi-Pinetum). The mooses lived in the reserve chiefly in the summer, whereas in the winter they moved also to its isolation zone and then to the other parts of the forest district, where the fresh coniferous forest (Vaccinio myrtilli-Pinetum) and fresh mixed coniferous forest (Pino-Quercetum) with its undergrowth covering $60 \%$ of the area in some sections predominated in dryer areas.

The osier-beds (Salici-Franguletum), large in area, with many species of Salix sp., Rhamnus frangula and relict Betula nana L., and also with rich ground cover consisting of many marsh plants, were of great importance to the moose in the forest district under discussion. These osier-beds formed a compact thicket, $1.5-2 \mathrm{~m}$ in height, securing the mooses excellent protection and at the same time providing them with large amounts of varied food.

The wet and marshy areas as well as dense osier-beds and undergrowth in the stand of trees made this terrain hard of access to hunters, which probably prevented the complete extinction of the mooses to a certain extent in the past. The activities connected with forest administration were limited there, the first management and surface division of the forest were executed in 1928, and in 1932 the moose habitation area was recognized as a reserve. The mooses were thus always relatively little disturbed in this area and the stand of trees has been little changed by man's husbandry. In 1971312 mooses were recorded in region 5, 144 of them in the Rajgród forest district.

In the Pomorze, Skórka and Jedwabna forest districts (regions 4, 11 and 12 -Fig. 1) the mooses lived in large forest complexes, in which more than $90 \%$ of the area was occupied by the coniferous forest habitats, chiefly the Vaccinio myrtilli-Pinetum association with Pinus silvestris L., growing on sandy and podsol soils, as its dominant species (Table 3). The poor undergrowth was enriched in some places by artifically introduced Prunus serotina L., Rhamnus frangula L., Salix caprea L., Sambucus nigra L. and Sorbus aucuparia L. 
A low percentage of the area of these districts was covered by fertile habitats or by wet forests and proper alder woods with thick undergrowth and varied ground vegetation. These occurred in the vicinity of seven lakes and a river in the Pomorze forest district (4), two lakes and a river in the Skorka district (11) and numerous depressions of the ground which formed small lakes drying up seasonally in the Jedwabna district (12). In these forest districts the osier-beds occurred as small brakes at the margins of meadows and in ground depressions.

A rather scanty but varied food base of mooses arose under these conditions. Forest exploitation was very intensive in these areas, leaving clear felling sites, $2-5$ ha in area, reforested with pinetrees with and admixture of the birch. In the Pomorze (4) and Skórka (11) forest districts there were young stands of pines, growing in forest parts destroyed by a fire, in which the mooses found shelter and food, especially in the winter. There were no differences between the summer and winter habitations of mooses there. They lived in coniferous forest habitats alternating with small patches of alder woods and other deciduous woods.

In the Trzebinia forest district (region 18-Fig. 1) mooses settled down in a medium-sized forest complex, in which the coniferous forest and especially moist coniferous forest (Vaccinio uliginosi-Pinetum molinietosum) habitats prevailed (Table 2). The withering of coniferous trees owing to the air pollution caused by a nearby industrial district and the change of the stands into those of deciduous trees prompted the development of thick and close undergrowth, in which Betula sp., Sorbus aucuparia L., Rhamnus frangula L., Populus tremula L. and numerous Salix sp. dominated. The vegetation of the ground cover was diversified and as a rule typical of coniferous forests.

There were no lakes or marshes in the form of bogs in this region, but the impervious substratum gave rise to local swamps, which had not been reclaimed in spite of a system of drain ditches. This whole region was frequently visited by the inhabitants of the nearby towns, it was traversed by a tourist track and, in addition, surrounded by busy lines of transport.

The deciduous forest habitats (Tilio carpinetum stachyetosum) predominated in the Wipsowo, Weggorzewo and Borki forest districts (regions 2 and 3 -Fig. 1), the coniferous forests and alder woods being less numerously represented (Table 3 ). The configuration of these forest districts was undulate and hilly, with a large number of lakes and a great variety of habitats. The osier-beds were of various size there, the undergrowth was exuberant, while the forest ground vegetation was fairly abundant only in places exposed to the sunshine. 
In the Wipsowo forest district, differentiated in respect of both physiography and habitats, there were 67 forest complexes, of which three were large: the main complex, about 5000 ha in area, Kikity, about 1000 ha, and Zagajnik, about 500 ha. Mooses, 10 in number, lived in the ranges Kikity and Zagajnik in 1971. These ranges were composed of mixed deciduous forests $(60 \%)$, mixed coniferous forests $(25 \%)$ and beeches, in contradistinction to the main complex, where the pine deciduous forests $(10 \%)$, with large numbers of spruces, oaks and beeches, in contradistinction to the main complex, where the pine prevailed in poored habitats. In 197120 mooses lived in the Weqgorzewo forest district (3), 12 of them in the range Sztynort, about 500 ha in area, situated on Lake Mamry and consisting exclusively of deciduous

Table 3

Number and area of forest complexes constituting moose habitations in 62 forest districts and size classes of inhabited complexes as exemplified by 23 forest districts.

\begin{tabular}{|c|c|c|c|c|}
\hline \multirow[t]{2}{*}{ Item } & \multirow{2}{*}{$\begin{array}{l}\text { Total in } \\
62 \text { forest } \\
\text { districts }\end{array}$} & \multicolumn{3}{|c|}{$\begin{array}{l}\text { Forest complexes in size classes } \\
\text { in } 23 \text { forest districts, in ha } \times 10^{3}\end{array}$} \\
\hline & & $0.3-1.0$ & $1.1-5.0$ & $>5.1$ \\
\hline Number of inhabited & & & & \\
\hline forest complexes & 163 & 5 & 18 & 10 \\
\hline Area, in 1000 ha & $\begin{aligned} 305.9 \\
1150\end{aligned}$ & $\begin{aligned} 3.3 \\
42\end{aligned}$ & $\begin{array}{c}51.2 \\
223\end{array}$ & $\begin{aligned} 86.1 & \\
258 & \end{aligned}$ \\
\hline Average density, in $n / 1000$ ha & 3.8 & 12.8 & 4.4 & 3.0 \\
\hline
\end{tabular}

forest and alder wood habitats, and 8 individuals in the range Kalskie Nowiny, made up of 800 ha of a fresh deciduous forest, alder and ash woods, and a small proportion of mixed coniferous forest. On the other hand, mooses were rerely met with in the range Pozezdrze, where the fresh coniferous forest predominated. In this forest district migrations of the mooses from the range Sztynort to the range Wielki Las, 2000 ha in area, abounding in deciduous and mixed coniferous forest habitats, were observed in the winter. The Borki forest district (3) was a part of the large Borecka Forest (28000 ha), in which the deciduous forest habitats prevailed. The highly mosaic distribution of different habitats there did not permit us to distinguish the part of the forest complex to which the mooses gave particular preference.

The intensive exploitation of forests was conducted in these districts, though in some places on a limited scale because of their marshy nature and inaccessibility in some seasons of the year. In the Wipsowo and Węgorzewo forest districts, regions situated in the neighbourhood of 
lakes were visited by large numbers of tourists and holiday-makers, disturbing the mooses in their habitation areas.

\subsection{Some of the Environmental Requirements of the Moose in Poland}

Mooses inhabited both medium-sized forest (from 300 ha upwards) and very large ones (above $5000 \mathrm{ha}$ ), reaching the highest density in the former and occurring most numerously in the latter (Table 3).

Table 4

Frequency of forest habitat types in 62 inhabited forest districts.

\begin{tabular}{lcc}
\hline Type of forest & \multicolumn{2}{c}{ Frequency } \\
& $\mathrm{n}$ & \% \\
\hline Mixed coniferous forest & 46 & 76 \\
Alder woods & 43 & 70 \\
Fresh coniferous forest & 32 & 52 \\
Deciduous forest & 28 & 46 \\
Mixed deciduous forest & 27 & 44 \\
Marshy coniferous forest & 17 & 28 \\
Moist coniferous forest & 10 & 16 \\
Dry coniferous forest & 8 & 13 \\
\hline
\end{tabular}

Table 5

Frequency of osier-beds and main species marking up the undergrowth in 62 forest districts inhabited by mooses.

\begin{tabular}{llc}
\hline Tree or shrub species & \multicolumn{2}{c}{ Frequency } \\
& $\mathrm{n}$ & $\mathbf{\%}$ \\
\hline Salix sp. (osier-beds) & 58 & 94 \\
Frangula alnus & 49 & 79 \\
Sorbus aucuparia & 32 & 51 \\
Corylus avellana & 32 & 51 \\
Betula sp. & 20 & 31 \\
Juniperus communis & 17 & 27 \\
Evonymus sp. & 16 & 26 \\
Padus avium & 15 & 24 \\
Populus tremula & 14 & 22 \\
Sambucus sp. & 12 & 19 \\
Tilia sp. & 9 & 14 \\
\hline
\end{tabular}

All the types of lowland forest habitats were represented in the forest complexes inhabited by mooses, the mixed coniferous forest and alder woods being the commonest and the dry, moist or marshy forests the least frequent (Table 4). The correlation between the population density of mooses and the surface areas of particular types of forest habitats was not significant. 
The deciduous and coniferous undergrowth and osier-beds provided mooses with food. Table 5 shows that the osier-beds occurred in nearly all forest districts $(94 \%)$ inhabited by mooses. In 4 districts (Serwy and Mikaszówka in region 4, Grajewo in region 5 and Kumiałka in region 6) the mooses did not find osiers in abundance. Lacking and deficient willows could be compensated with trees and shrubs dominating in the undergrowth and so, above all, with the alder buckthorn, rowan and birch. In 3 forest districts which the mooses traversed without stopping for a fairly long time there were no osier-beds or large quantities of the rowan and alder buckthorn in the undergrowth, which indicates the importance of these species to the moose.

\section{Table 6}

Frequency of water resorvoirs in 62 forest districts inhabited by mooses.

\begin{tabular}{lcc}
\hline Sort of water reservoirs & \multicolumn{2}{c}{ Frequency } \\
& $\mathrm{n}$ & \% \\
\hline Marshes & 61 & 98 \\
Rivers & 49 & 79 \\
Lakes & 39 & 64 \\
\hline
\end{tabular}

Table 7

Physiography of the terrains in 36 forest districts inhabited by mooses.

\begin{tabular}{lccc}
\hline Terrain & \multicolumn{3}{c}{ Number of } \\
\cline { 2 - 4 } & Forest districts & Mooses & ha/moose \\
\hline Flat & 9 & 250 & 208 \\
Undulate & 17 & 276 & 360 \\
Hilly & 3 & 25 & 320 \\
Diverse & 7 & 122 & 230 \\
\hline
\end{tabular}

All the areas inhabited by the moose abunded in water. Marshes were very frequent, only one district (Wąkole in region 12) lacked typical marshes, but there were wet riverside osier-beds instead. Lakes were present in narly four-fifths of the forest districts examined, whereas rivers and canals were rarer (Table 6). In six forest districts there were no lakes or rivers but considerable marshy and wet areas in the habitation regions of the moose.

Reliable information about the configuration of the areas inhabited by mooses were obtained for 36 forest districts situated in all the regions colonized by this animal (Table 7 ). On the basis of these data it might be supposed that mooses find the most favourable conditions. 
in flat regions and the least favourable ones in undulate and hilly areas. However, the largest number of mooses lived in undulate regions, their number being somewhat smaller in flat regions and the smallest in hilly ones. Mooses have not, as yet, settled down in the mountains.

The degree of disturbance by mushrooming and berrying as well as by tourists and traffic on nearby transport lines was various but generally high in the moose habitation areas. This indicates that the mooses managed to adapt themselves to the presence of man and to modern civilization. In 12 forest districts there were several simultaneously acting disturbing factors; nevertheless, the mooses settled down in them and, what is more, increased in number. Tolerable quiet prevailed in $40 \%$ of moose habitation areas, allowances being made for normal forest management activities.

In the habitation areas disturbed by the presence and activity of man the mooses showed little shyness, whereas in some areas lying in reserves they were somewhat shyer. Forest exploitation by clear or partial cutting did not prevent the moose from expansion in any of its habitation regions. The drainage system laid down in regions 5 and $18 \mathrm{did}$ not as a rule influenced the number of the mooses. They lived also in forests affected by dusts and gases emitted by the factories of the nearby industrial centre in region 18 .

\section{FACTORS AFFECTING MOOSE POPULATION SIZE}

\subsection{Population Growth}

The real growth of an moose population was expressed by the percentage ratio of the number of calves to that of cows censused towards the end of the winter.

The real increase in the number of mooses was different in particular years and habitation areas (Table 8 ). In Poland it averaged $64 \%$ in 1962 , $42 \%$ in 1968 and $52 \%$ in 1971 . In general, in 1968 the real population growth decreased in comparison with 1962 in densely populated regions and in 1971 it increased in comparison with 1968, especially in the regions in which shooting-parties were held. In the case of migrating mooses the increase in number was $38 \%$ in 1971 .

The data concerning the numbers of mooses and areas inhabited by them obtained during this study permitted a comparison of the density and real growth of populations (Table 9). Spearman's correlation coefficient (range correlation - Z i e li ńs ki, 1971) calculated for these data was $r=-0.665$. Thus, the correlation is significant $(P=0.05)$, which means that the real population growth of mooses decreases with an 
increase in density. In the low-density areas $(2.1-3.0$ mooses per 1000 ha) the real population growth ranged between 50 and $63 \%$, in the medium-density areas $(3.1-4.0$ mooses per $1000 \mathrm{ha})$ it was $36-67 \%$ and in the high-density areas $(4.1-8.0$ mooses per 1000 ha) $34-45 \%$ of the number of cows. The emigration of mooses from the areas more densely populated was consequently found to be greater $(4,5,13$ and 17).

Table 8

Real moose population growth expressed by the number of calves in regions inhabited by more than 30 individuals and in all the remaining regions together.

\begin{tabular}{|c|c|c|c|c|c|c|}
\hline \multirow[t]{2}{*}{ Region number * } & \multicolumn{2}{|c|}{1962} & \multicolumn{2}{|c|}{1968} & \multicolumn{2}{|c|}{1971} \\
\hline & $\mathrm{n}$ & $\%$ of $q$ ㅇ & $\mathrm{n}$ & $\%$ of $q$ q & $\mathrm{n}$ & $\%$ of $q$ 우 \\
\hline 2 & - & - & - & - & 17 & 59 \\
\hline 3 & - & - & 16 & 55 & 50 & 68 \\
\hline 4 & - & - & 35 & 49 & 58 & 67 \\
\hline 5 & 43 & 56 & 52 & 27 & 52 & 34 \\
\hline 6 & - & - & - & - & 10 & 36 \\
\hline 8 & - & - & - & - & 8 & 62 \\
\hline 11 & - & - & - & - & 9 & 64 \\
\hline 12 & - & - & 8 & 50 & 23 & 47 \\
\hline 13 & 16 & 107 & 26 & 65 & 22 & 45 \\
\hline 14 & - & - & - & - & 9 & 43 \\
\hline $\begin{array}{l}1,7,9,10,15 \\
16,17,18 \\
\text { Subtotal }\end{array}$ & 5 & 45 & 22 & 61 & 30 & 62 \\
\hline Total/Average & 64 & 64 & 161 & 42 & 288 & 52 \\
\hline
\end{tabular}

* Region numbers same as in Table 1 and Fig. 1 .

Table 9

Density and real population growth of the moose in some habitation regions.

\begin{tabular}{|c|c|c|c|c|c|}
\hline $\begin{array}{l}\text { Region } \\
\text { number * }\end{array}$ & $\begin{array}{l}\text { Number of } \\
\text { forest } \\
\text { districts }\end{array}$ & $\begin{array}{l}\text { Number of } \\
\text { moose living } \\
\text { in these } \\
\text { districts }\end{array}$ & $\begin{array}{c}\text { Area of } \\
\text { habitation }\end{array}$ & $\begin{array}{l}\text { Density, } \\
\text { n/1000 ha }\end{array}$ & $\begin{array}{l}\text { Real } \\
\text { growth, } \\
\text { in } \% \\
\text { of } 9 \text { 우 }\end{array}$ \\
\hline 1 & 2 & 21 & 6.3 & 3.3 & 64 \\
\hline 2 & 6 & 65 & 26.8 & 2.4 & 59 \\
\hline 3 & 13 & 154 & 74.8 & 2.1 & 68 \\
\hline 4 & 11 & 217 & 62.6 & 3.5 & 67 \\
\hline 5 & 5 & 312 & 38.7 & 8.0 & 34 \\
\hline 6 & 4 & 44 & 14.1 & 3.1 & 36 \\
\hline 7 & 1 & 8 & 3.0 & 2.7 & 50 \\
\hline 12 & 7 & 116 & 32.2 & 3.6 & 47 \\
\hline 13 & 2 & 98 & 22.6 & 4.3 & 45 \\
\hline 14 & 2 & 38 & 9.0 & 4.2 & 43 \\
\hline 17 & 23 & 26 & 5.5 & 4.7 & 38 \\
\hline Total/Avg. & 56 & 1099 & 295.6 & 3.7 & 54 \\
\hline
\end{tabular}

* Region numbers same as in Table 1 and Fig. 1. 


\subsection{Sex Ratio}

In this study the sex ratio of an moose population is expressed as the ratio of the number of bulls to cows living in particular habitation regions. It will be seen from Table 10 that it ranged from 0.63 to 1.07

\section{Table 10}

Ratio of moose males to females calculated for regions with more than 30 individuals and for all the remaining regions together as well as for the whole territory of Poland.

\begin{tabular}{cccc}
\hline Region number * & 1962 & 1968 & 1971 \\
\hline 2 & - & - & 0.83 \\
3 & - & 0.72 & 0.89 \\
4 & - & 0.89 & 0.77 \\
5 & 1.07 & 0.74 & 0.79 \\
6 & - & - & 0.93 \\
8 & - & - & 1.00 \\
11 & - & 1.06 & 0.64 \\
12 & 0.87 & 0.63 & 0.65 \\
13 & - & - & 0.86 \\
14 & 0.73 & 0.97 & 0.77 \\
\hline $1,7,9,10,15,16,17,18:$ Subtotal & 0.99 & 0.79 & 0.81 \\
\hline Total & & &
\end{tabular}

* Region numbers same as in Table 1 and Fig. 1.

in different regions, averaging $0.99,0.79$ and 0.81 in 1961, 1968 and 1971 , respectively. The fact that the takes of bulls were greater influenced the sex ratio in favour of cows (Table 12). As regards the mooses wandering about Poland, the bulls outnumbered the cows (1.11).

\subsection{Mortality and Takes}

The losses in an moose population were divided in this study into three groups: natural losses (caused by factors occurring in nature), unnatural ones (caused by man and his activities) and allowable takes.

In addition to the data collected personally or by means of questionnaires, the reports of the death of 17 mooses published in 1950-1971 were also taken into consideration (Brodziński, 1967; Bruźd zi a k, 1964; F a fiński, 1969; G os i e w ski, 1961, 1970; K a niewski, 1966; Łapiński, 1970; Molski, 1967; Mól, 1970, 1972; Pielowski, 1969; Kochan \& Tomek, 1969; Trzeciak, 1965; Wolanski, 1964). Naturally, the losses in the moose populations given in this paper do not include all the cases of perished animals but only those known to the staff of the forest administration.

A total of 499 mooses died in 1960-1971, of which 363 individuals 
were shot and 134 died of other causes. Table 11 shows that out of these 134 mooses, $55(41 \%)$ died a natural death, $47(35 \%)$ died of unnatural causes, and in 32 cases $(24 \%)$ the cause of death remained unexplained. Diseases caused the death of the following numbers of mooses in Poland: rabies -4 , liver disease -2 , Bollinger's disease -1 , inflammation of alimentary canal -1 and choke -1 . In 14 cases the disease was not established. A certain number of mooses were drowned in marshes and peatbogs and died of mechanical injury, the commonest of which was the fracture of limbs. There are some cases on record, in which people came to the rescue of a drowning moose (B \& a szczak, 1966; I wanowski, 1965) or cured a wounded animal (H e y m a now ski, 1967).

Table 11

Moose death records in Poland in 1960-1971.

\begin{tabular}{|c|c|c|c|c|c|c|}
\hline \multirow{2}{*}{ Cause of death } & \multicolumn{4}{|c|}{ Number of mooses } & \multicolumn{2}{|c|}{ Total } \\
\hline & Bulls & Cows & Calves & $\begin{array}{c}\text { Sex } \\
\text { unidentif. }\end{array}$ & $\mathrm{n}$ & $\%$ \\
\hline
\end{tabular}

Natural

Drowning

Disease

Mechanical injury

Injury during mating

Beasts of prey

Unnatural

Poaching

Dogs

Means of transport

Unidentified

$\begin{array}{rrrr}2 & 1 & - & 10 \\ 3 & 5 & 2 & 13 \\ 2 & 1 & - & 9 \\ 4 & - & - & - \\ - & - & - & 3\end{array}$

$\begin{array}{rr}13 & 10 \\ 23 & 17 \\ 12 & 9 \\ 4 & 3 \\ 3 & 2\end{array}$

\begin{tabular}{lllllll}
\hline Total & 25 & 15 & 5 & 89 & 134 & 100 \\
\hline
\end{tabular}

The only wild beast of prey dangerous to the moose in Poland is the wolf; nevertheless, hunting stray dogs managed to kill 5 mooses.

The unnatural factors consist chiefly of poaching. There are reports of mooses captured in snares, killed e.g. with forks, axes etc., sometimes by an organized group of people, and shot illegally. Poaching occurred in Poland both a hundred years ago ( $\mathrm{Skibiński,} \mathrm{1961)} \mathrm{and} \mathrm{after}$ the Second World War, at the time of the closest protection of this species (M olsk i, 1957).

Shooting was initiated in 1966 in the Rajgród forest district (in region 5), where 27 mooses were taken in the first two years (19661967). In 1968-1971 338 individuals were shot in 10 densely populated areas, chiefly in region 5 (Table 12). Shooting was done, above all, in the habitation areas in which the mooses caused heavy damage to 
the forest economics. Although the takes were increased in those years, their annual average (about 110 specimens) in 1968-1971 did not exceed $40 \%$ of the real population growth and the increase in the number of mooses in Poland was not stopped (Fig. 3). Only in the habitation area in the Biebrza Basin the higher takes caused a reduction in the size of the moose population.

\section{Table 12}

Number of mooses shot in Poland in 1968-1971.

No. indicates region number, B - Bulls, C-Cows, Ca-Calves, T-Total.

\begin{tabular}{|c|c|c|c|c|c|c|c|c|c|c|c|c|c|c|c|c|}
\hline \multirow[t]{2}{*}{ No. * } & \multicolumn{4}{|c|}{$1968 / 69$} & \multicolumn{4}{|c|}{$1969 / 70$} & \multicolumn{4}{|c|}{$1970 / 71$} & \multicolumn{4}{|c|}{ Total in $1968-71$} \\
\hline & B & C & $\mathrm{Ca}$ & $\mathrm{T}$ & B & $\mathrm{C}$ & $\mathrm{Ca}$ & $\mathrm{T}$ & B & $\mathrm{C}$ & $\mathrm{Ca}$ & $\mathrm{T}$ & B & C & $\mathrm{Ca}$ & $\mathrm{T}$ \\
\hline 2 & - & - & - & - & 1 & 1 & - & 2 & 一 & - & - & - & - & 1 & 一 & 2 \\
\hline 3 & 1 & 1 & - & 2 & 4 & 2 & - & 6 & 7 & 3 & 3 & 13 & 12 & 6 & 3 & 21 \\
\hline 4 & 6 & 6 & 1 & 13 & 5 & 13 & 4 & 22 & 6 & 7 & 2 & 15 & 17 & 26 & 7 & 50 \\
\hline 5 & 35 & 26 & 11 & 72 & 46 & 36 & 20 & 102 & 30 & 26 & 18 & 74 & 111 & 88 & 49 & 248 \\
\hline 6 & - & - & - & - & 1 & - & - & 1 & 2 & 1 & - & 3 & 3 & 1 & - & 4 \\
\hline 9 & - & - & - & - & 1 & - & - & 1 & 5 & - & - & 5 & 6 & - & - & 6 \\
\hline 12 & - & - & - & - & 1 & - & - & 1 & 2 & 1 & - & 3 & 3 & 1 & - & 4 \\
\hline 13 & - & - & - & - & - & - & - & - & - & - & 1 & 1 & - & - & 1 & 1 \\
\hline 14 & - & - & - & - & 1 & 1 & - & 2 & - & - & - & - & 1 & 1 & - & 2 \\
\hline
\end{tabular}

\section{DISCUSSION}

A comparison of my own data with those given in $\mathrm{H}$ a be r's (1962) paper made it possible to determine the increase in the number of mooses in Poland. The appropriate curves (Figs. 2 and 3), resembling the exponential curves in shape, are typical of the species that enter a new territory providing them with favourable living conditions (MacArthur \& Connel, 1971) and indicate the constant development of the moose population. The excessive takes and lack of protection caused a drop in the number of mooses in the past but in 1946-1971 man, taking mooses under his protection, made their return tc the previously abandoned areas possible. This is in a certain measure indicated by the short-lived and local increase in the number of mooses in the Wilno Province between the Wars, when they had been taken under protection ( $\mathrm{Miklaszewski,} \mathrm{1947).} \mathrm{It} \mathrm{may} \mathrm{well} \mathrm{be,} \mathrm{as} \mathrm{well,}$ that in the previous centuries the moose withdrew from its habitation areas owing to deforestation and the spread of human activities and in the twentieth century it acquired characters which permitted it to adapt itself to the existing natural and forest conditions and to return to the regions that it had left before. Similar fluctuations in the number of mooses were found in the territory of the Soviet Union, where the regression of this species lasted to the beginning of the twentieth century 
and where after the introduction of protection in the twenties of this century their number and occurrence area increased ( $\mathrm{Heptne} \mathrm{r}$ et al., 1961; Heptner \& N asimovich, 1967). An analogous situation has also been observed in Sweden ( $\mathrm{S} \mathrm{k} \mathrm{uncke}, 1949)$ and in Norway and Finland (N ow a k, 1971).

In the period of moose regression the opinion prevailed that this animal rather inhabits large forest complexes and marshy regions hard of access and uncultivated (Korsak, 1934; Petrusewicz \& "iochterman, 1963). It is true that in Poland the moose managed to survive the regression period only in such regions, but increasing in number, it spread all over the country, and settled down, to a great extent, in areas characterized by living conditions which sometimes differed much from those in the original habitation area in the Biebrza Basin.

Recently, some authors expressed their opinion that the moose is able to adapt itself to different living conditions ( $\mathrm{Heptner}$ et al., 1967) and to the vicinity of man ( $\mathrm{Kn}$ or re, 1959; Tomek, 1969). Similarly, on the basis of the rate of its spreading in Eurasia, Now a k (1971) counted the moose among the species that are poorly specialized and have a high ecological valency. The investigation presented in this paper confirms the rightness of these statements.

This investigation confirms also the earlier observations on the moose's disposition to long migrations (K o r s a k, 1934; P i e low sk i, 1969; Serafinski, 1969; Nowak, 1971). The age of the mooses which having come from Poland died in Germany or Czechoslovakia (Briederman, 1968; Gyimesi, 1971) suggests that juveniles predominate among the migrating specimens. The highest intensity of migration was observed in the spring and autumn. There were however no seasonal migrations to other remote habitation areas, like those in Canada (Peterson, 1955) and in the USSR (Heptner \& Nasimovic h, 1967).

So far, the population growth of mooses has been studied by different methods and expressed by means of different indices. The reproductive ability of cows exerts a decisive influence on its height, and it is known from direct observations that each of them can give birth to 1 , at a middle age to 2 or, exceptionally, 3 calves yearly ( $\mathrm{K} n$ or re, 1959; Heptner et al., 1961). According to Pielowski (1969), the number of calves falling to one cow in the Kampinos National Park was $0.9-2.0$ in different years. On the basis of the corpora lutea examined in 930 cows, Markgren (1969) found that the ovulation index ranged from 1.11 to 1.56 in different parts of Sweden, being the highest 
for rich habitats and for middle-aged cows. If this index is similar in Poland, its comparison with the real population growth $(42-64 \%$ of the number of cows) may indicate a high mortality rate of embryos or calves in the first months of life or a high uncontrolled take of game. The most calves die in the first and second months of life ( $\mathrm{Kn}$ or re, 1959) and for this reason it is important to the planning of game management to determine the real population growth, i.e. the number of calves that have survived the early early period of life.

Most authors calculate the real population growth of mooses in relation to the population size. In Poland the population growth thus calculated averaged $32 \%$ in $1962,23 \%$ in 1968 and $29 \%$ in 1971 . Thus, it was similar to that in the European territory of the USSR ( $\mathrm{H} \mathrm{e} \mathrm{pt-}$ ner et al., 1961; Y urgenson, 1964), higher than in Canada (P eterson, 1955; Edwards \& Ritcey, 1959) and somewhat lower than in Sweden ( $\mathrm{Sk} \mathrm{uncke}$, 1949). The increase in number calculated in relation to the population size does not provide full information about the reproductive potential of a population, because it does not allow for sex ratio. The sex ratio in moose populations may be $1: 1$ or it favours cows. Yazan (1964) found the sex ratio of moose embryos to be $1: 1$. Similarly, Ser a fins ki (1969) states that in the Kampinos National Park (13) males and females were born in equal numbers. $\mathrm{He}$ etner et al. (1961) write that in 50 litters observed in the territory of the USSR males formed $56 \%$ of the newborns, but owing to their higher losses the sex ratio became settled at $1: 1$ in unexploited populations. On the other hand, Serafinski (1969) shows that in a highdensity moose population under protection the ratio was $1: 1.24-1: 1.60$ in favour of females owing to the more numerous emigration of bulls. In exploited populations of different regions of the USSR the sex ratio varied within limits of $1: 1.02-1: 1.50$ in favour of cows ( $Y$ u r g ens o n, 1964). Similarly, in Alaska and British Columbia the fewest bulls occurred in the most intensely exploited areas ( $\mathrm{Peterson}, 1955)$. The sex ratio of mooses in their habitation areas in Poland (on the average $0.79-0.98$ ) was probably influenced both by the above-mentioned more numerous emigration of bulls and by higher takes, for the number of bulls taken was higher than that of cows by $24 \%$.

In 1971 the density of mooses in Poland averaged 2.1-8.0 specimens per 1000 ha and it resembled that in Sweden ( $\mathrm{Krott}, 1956)$ and in the USSR (Bannikov \& Teplov, 1964), from where it was reported to be, respectively, $2.7-6.0$ and $0.5-5.9$ specimens per 1000 ha. However, within a given region it sometimes differed considerably between particular forest districts, in which it resembled the situation 
in the USSR, where in the reserves the density of mooses was 5-14 times as high as the mean for the given region (A leksandrova, 1957; B annikov \& Teplov, 1964).

Serafinski (1969) put forth the opinion that the reproductiveness of mooses depends on density. The present investigation has confirmed that the real growth of an moose population and its density vary inversely. It has also shown that the real population growth increased, after moose shoots had been reintroduced in densely populated areas.

The takes of mooses were smaller than the real population growth and, in consequence, the dynamics of the increase of their number in Poland was only slightly lowered (Figs. 2 and 3). It seems that the regression of the moose observed in previous centuries has been stopped and as for now there is no danger of the extinction of this species in Poland, which danger still existed 20 years ago.

\section{REFERENCES}

1. Aleksandrova J. V., 1957: Materiały po čislennosti losej v Prioksko-Terrasnom Zapovednike i v Moskovskoj Oblasti. Tr. Prioksko-Terrasnogo Gos. Zap., 1: 144-156.

2. Bannikov A. G. \& Teplov V. P., 1964: Dviženie čislennosti i plotnosti naselenija losja $\mathrm{v}$ RSFSR. Biologija i promysel losja, 1: 5-12. Moskva.

3. B 1 a s z c z y k M., 1966: Uczniowie ratują łosie. Łow. Pol., 17: 14.

4. Bobek B. \& Tomek A., 1973: Uwagi o liczeniu zwierzyny. Łow. pol., 8: $2-3$.

5. Bogucki Z., 1967: Kilka uwag o ankietowym badaniu ptaków. Przegląd Zool. 11, 2: 161.

6. Brie dermann L., 1968: Die Westvorstösse des Elchwildes (Alces a. alces L.) in Mitteleuropa in ihrer populations-dynamischen Bedeutung. Zoolog. Garten, 35, 4/5: $224-229$.

7. Brodziński J., 1967: Tragedia losia. Łow. pol., 3: 14.

8. Bruździak W., 1964: Łoś ofiarą wałęsającego się psa. Łow. pol., 19: 15.

9. Chudik I. \& Sladek J., 1962: Los velky (Alces alces L.) na Slovensku. Biologia, 12, 8: 614-620. Bratislava.

10. Edwards K. \& Ritcey K., 1959: Reproduction in a moose population. J. Wildl. Manage., 22, 3: 261-268.

11. F a fiński W., 1969: Łoś w olsztyńskim. Zachodni Poradnik łow. 10, 3: $23-24$.

12. Gos i e wski H., 1961: Łoś ofiarą zarazy. Łow. pol., 24: 14.

13. Gosiewski H., 1970: Trzeci łoś ofiarą kłusujących psów. Łow. pol., 12: 14.

14. Gusta wicz B., 1901: Geograficzny zasiąg łosia ongi i dzisiaj. 1-43. Lwów.

15. Gy imesi J., 1971: Imigracie losa mokradoveho zapadnego (Alces alces L.) 1758) do CSSR. Polovnicky Zbornik, 1: 217-224.

16. H a ber A., 1962: Łoś europejski w Polsce. Referat Polskiego Towarzystwa Leśnego. 1-31. Warszawa. 
17. Heptner V. G. \& Nasimovich A. A., 1967: Der Elch. Die Neue Brehm Bücherei: 1-231. Wittenberg-Lutherstadt.

18. Heptner V. G., Nasimovich A. A. \& Bannikov A. G., 1961: Mlekopitajušce Sovetskogo Sojuza. Parnokopytnye i neparnokopytnye. Izd. „Vysšaja Škola”: 1-776. Moskva.

19. Heydenreich H. C., 1958: Vereinzelte Elchvorkommen in Ostpreussen 1958. Zeitschr. Jagdwiss., 4, 1: 33-34.

20. Heydenreich H. G., 1961: Elchwanderungen in Europa von 1957-1960. Zeitschr. Jagdwiss., 7, 2: 83-86.

21. H e y man ow ski K., 1967: Przygoda Sylwiusza. Łow. pol., 4: 5.

22. I wa nowski C., 1966: Łosie w Wielkopolsce. Zachodni Poradnik łow. 7, 1: $12-16$.

23. Ka empf T., 1966: Obserwacje nad łosiami w Puszczy Kampinoskiej. Łow. pol., 1: 5 .

24. K a n i e wski W., 1966: Tragedia łosia. Łow. pol., 7: 14.

25. K arpiński J. J., 1952: Łoś (Alces alces L.) w Puszczy Białowieskiej. Chr. Przyr. Ojcz., 7, 11/12: 40-47.

26. Knorre E. P., 1959: Ekologia losja. Tr. Pečoro-Ilyčskogo Gos. Zap., 7: 5-122.

27. Knorre E. P., 1969: Izmenenie povedenia losja $\mathrm{v}$ processe ego odomašnivania. Tr. Mosk. Ob. Isp. Prirody, 35: 13-20.

28. Kochan W. \& Tomek A., 1970: Smierć łoszy w Puszczy Dulowskiej. Chr. Przyr. Ojcz., 26, 4: 44.

29. Korsak W., 1934: Łoś w Polsce. Państwowa Rada Ochrony Przyrody: 1-47. Warszawa.

30. Kowalski K., 1971: Ssaki-zarys teriologii. Państw. Wyd. Nauk.: 1-641. Warszawa.

31. Krott P., 1956: Zur Aufzucht von Elchkälbern. Zeitsch. Jagdwiss., 2, 1: 1-11.

32. Ła piński W., 1970: Wścieklizna łosia. Łow. pol. 11: 14.

33. MacArthur R. H. \& Connel J. H., 1971: Biologia populacji: Państw. Wyd. Roln. Leśne: 1-232. Warszawa.

34. Markgren G., 1969: Reproduction of moose in Sweden. Viltrevy, 6, 3: $127-299$.

35. Miklaszewski J., 1947: Rzut oka na dzieje i stan leśnictwa i łowiectwa polskiego w okresie 1918-1939. Sylwan, 91, 1-4: 10-31.

36. Molski B., 1957: W sprawie łosia. Łow. pol., 17: 9.

37. Mól H., 1970: Wścieklizna w pierwszym półroczu $1970 \mathrm{r}$. Łow. pol, 15-16: 14.

38. Mól H., 1972: Wścieklizna zwierząt w 1971 r. Łow. pol., 3: 10-11.

39. Nowak E., 1971: O rozprzestrzenianiu się zwierząt $\mathrm{i}$ jego przyczynach. Zeszyty naukowe IE PAN, 3: 1-251.

40. P a s 1 a wski T., 1971: Łosie problemy. Łow. pol., 12: 5 .

41. Peterson R. L., 1955: North American moose. 1-280. Toronto.

42. Petrusewicz K. \& Tochterman J. J., 1936: Zwierzyna łowna lasów północno-wschodniej Polski. Ochr. Przyr., 16: 151-157.

43. Pielowski Z., 1969: Die Wiederienbürgerung des Elches (Acles alces L.) in Kampinos-National Park in Polen. Zeitschr. Jagdwiss., 15, 1: 6-17.

44. Sapetin J. E. \& Priklonskij S. G., 1964: Pereščetnyj koeficient maršrutnogo učeta losej. Biologija i promysel losja, 1: 122-126. Moskva.

45. Serafińska W., 1969: Reproduction and dynamics of moose (Alces alces L.) population in the Kampinos National Park, Ekol. pol., A, 17: 709-718.

46. Skibiński S., 1961: Odwieczna tragedia łosi. Łow. pol., 3: 15. 
47. Sk uncke F., 1949: Algen Studier, jakt, och vand. Stockholm.

48. Stadion-Rzyszczewski J., 1960: Łoś wśród zwierząt łownych. Łow. pol., $8: 4$.

49. Szczepkowski J. J., 1969: Polujemy na łosie. Łow. pol., 21: 8-9.

50. Tomek A., 1969: Łoś w Polsce w ostatnim XX-leciu. Zachodni Poradnik low. 10, 2: 3-9.

51. Trzeciak T., 1965: Wędrówki łosi. Łow. pol., 21: 15.

52. Wolański S. H., 1964: Dramat w Kampinosie. Łow. pol., 23-24: 23.

53. Y a z a n J., 1964: Plotnost, naselenie i pokazateli plodovitosti losja pečorskoj tajgi. Biologia i promysel losja, 1: 101-113. Moskva.

54. Yurgenson P. B., 1964: Struktura i sostav populacji losja v lesnyh ohotničih ugodjah. Biologia i promysel losja, 1: 13-34. Moskva.

55. Zieliński R., 1972: Tablice statystyczne. Państw. Wyd. Nauk.: 1-391. Warszawa.

Accepted, April 27, 1977

\section{Andrzej TOMEK}

WYSTĘPOWANIE I NIEKTORE PARAMETRY EKOLOGICZNE ŁOSIA W POLSCE

\section{Streszczenie}

Łoś, Alces alces (Linna eus, 1758) nie był w Polsce dotychczas objęty szerszymi badaniami a w związku z gwaltownym wzrostem jego liczebności wynikła konieczność poznania jego występowania i niektórych cech ekologicznych.

Miejsca bytowania, tereny wędrówek i ubytki łosi poznano $\mathrm{z}$ ankiet wypełnionych przez nadleśnictwa w 1968 i 1971 r. Szczegółowe badania terenowe przeprowadzono natomiast w 8 nadleśnictwach stanowiących ostoje i 3 nadleśnictwach objętych wędrówkami. Ponadto w 1971 r. zebrano dane z 62 nadleśnictw dotyczące warunków bytowania i liczebności łosia.

W wyniku badań stwierdzono, że w 1971 r. łoś bytował w Polsce w 88 nadleśnictwach, które można było pogrupować na 18 rejonów (Ryc. 1). Do roku 1971 wzrastała liczba łosi i terenów przez nie zasiedlonych (Ryc. 2 i Ryc. 3). W latach 1968-1971 liczebność wzrastała o 15\% rocznie (Tabela 1). Łoś mógł zasiedlać obszary nizinne o różnych warunkach terenowych (Tabela 2 i Tabela 7 ) z różnymi typami siedliskowymi lasu (Tabela 4). Największa liczba łosi bytowała w dużych kompleksach leśnych, chociaż większe ich zagęszczenie było w kompleksach mniejszych (Tabela 3). W nadleśnictwach zasiedlonych przez łosie w większości występowały bagna (Tabela 6) i rosła bogata roślinność drzew i krzewów w podszycie (Tabela 5).

Przyrost realny populacji łosi wynosił $42-64 \%$ liczby klęp (Tabela 8), a stosunek byków do klęp wynosił 0.79 do 0.99 (Tabela 10), średnie zagęszczenie wahało się od 2.1 do 8.0 osobników na 1000 ha powierzchni leśnej (Tabela 9). Ponadto stwierdzono wędrówki 144 łosi po 315 nadleśnictwach.

Zarejestrowano 134 przypadki ubytków łosi, głównie wskutek kłusownictwa, chorób i utonięć (Tabela 11), a w latach 1968-1971 odstrzelono łącznie w Polsce 
338 osobników w 10 rejonach bytowania (Tabela 12). Pomimo corocznego zwiększania odstrzałów pozyskiwano około $40 \%$ przyrostu realnego dzięki czemu nie zahamowano wzrostu liczebności tego gatunku. W ostojach przegęszczonych wystąpiła tendencja do autoregulacji zagęszczenia przez migracje i zmniejszenie przyrostów. Nie stwierdzono większego wpływu działalności gospodarczej człowieka na rozwój i bytowanie łosi w Polsce.

Wydaje się, że łoś znalazł w Polsce dogodne warunki bytowania i jego liczebność będzie się zwiększała nadal. Regresja istniejąca w ubiegłych wiekach mogła być spowodowana przez człowieka, lecz po wprowadzeniu ochrony, łoś wykazał zdolność przystosowania do różnych zmienionych warunków środowiska. Znikła zatem groźba wyginięcia tego gatunku na ziemiach Polski. 